\title{
Temporal and Aspectual Forms of Verbs in Proposition of Commissive Speech Acts: the Case of Promise, Swear and Bet
}

\author{
Konstantin Khomutskii \\ National Research University Higher School of Economics \\ Correspondence concerning this article should be addressed to Konstantin Khomutskii, 26 Shabolovka St., \\ Moscow, Russian Federation, 119049.E-mail: khomutskiy@hse.ru
}

\begin{abstract}
Numerous research on Speech Act Theory considers the pragmatic functions of various types of speech acts, their illocutionary forces and implementation in language, focusing either on their locutionary, illocutionary and perlocutionary constituents or on their taxonomies, whereas the analysis of semantic and syntactic properties of performative formula remains scarce. The present paper reports on the study of temporal perspective of commissive speech acts in the English language. Specifically, it examines temporal-aspectual forms in propositions of performative verbs of promise, swear and bet. The methodology to investigate temporal-aspectual features of verbs in proposition includes literature review and a continuous sampling method with the help of which the author analysed approximately 1,800 performative utterances containing commissive performative verbs. The results of research demonstrate that the set of temporal-aspectual forms as well as their frequency differ from one commissive under the study to another, while the syntactic structures of propositions is homogeneous. The study also established the correlation between the illocutionary force of commissive performative verbs and temporal-aspectual forms of verbs in proposition. The results of the study might have practical implications in teaching English as a foreign language in terms of grammar and sociocultural aspects.
\end{abstract}

Keywords: speech act theory, performative utterance, performative verb, commissive, proposition, temporal perspective

At the present stage of its development, linguistics puts an emphasis on the function of various language units. A verb is instrumental in the understanding of language function and is considered to be one of the most essential parts of speech. Generally, a verb presents the action of a doer and a certain verb is associated with a specific movement (action). For example, uttering a phrase 'I am walking', the mind subconsciously creates a picture of movement at a regular pace by lifting and setting down each foot in turn, never having both feet off the ground at once. The same is true for the following phrase 'I am writing' which depicts a process of writing i.e. marking (letters, words, or other symbols) on a surface, typically paper, with a pen, pencil, or on a computer screen. However, not every verb can be 'visualised' by an action. Thus, pronouncing 'I promise' or 'I swear' one cannot draw a picture of doing something as in cases of 'I am walking' or 'I am writing'. These are examples of performative utterances which contain performative verbs 'promise' and 'swear' respectively. Performative verbs combine the action itself and the description of that action, so the speech act is performed indirectly.

\section{Materials and Methods}

Initial remarks on different nature of performative verbs were made by Wittgenstein in his view about language-games. Developing the concept of 'the descriptive fallacy' in the frame of logical positivism, Wittgenstein (1953) noticed that some utterances resist a truth-conditional analysis, that is, these utterances can be named true or false. Thus, it can be stated that the utterance 'I promise this will never 
happen again' is true because communicants are not sure about the speaker's sincerity. Wittgenstein (1953) just mentioned that phenomenon without any further attempts to explain. However, such discrepancy in 'the descriptive fallacy' drew Austin's (the Oxford philosopher) attention and in the 1960s he formed the principles of Speech Acts Theory, which were later presented in the series of lectures 'How to do things with words', where he coined the term 'performative utterance'.

Performative utterances differ from constative ones in a number of ways. First, as mentioned above, constative utterances have the property of being true or false, while performative utterances can never be either. Austin (1962) proposed another binary opposition of 'felicitous and infelicitous' utterances, where he established a set of conditions. For instance, the speech act of promising will be felicitous provided that what is promised by the speaker is something the addressee wants to happen. Thus, it can be argued that Wittgenstein's concept of 'descriptive fallacy' in logical positivism transformed into 'felicity conditions' in Austin's 'Speech Act Theory'.

Second, performative utterances can fall into two types: explicit and implicit. Let us consider two utterances below: (1) and (2). (1) contains a performative verb which makes it clear what kind of speech act is being performed, while (2) has no such verb, thus making the aim of utterance unobvious. Compare below:

(1) I promise I will consider this issue later.

(2) I will consider this issue later.

Pronouncing (1) the speaker certainly performs a speech act of promising. However, utterance (2) can be regarded as a promise, a warning, or even a threat.

Third, explicit performative utterances possess a number of syntactic and semantic characteristics, the main of which is the use of a performative verb with a first person singular subject of a predicate (verb) in the indefinite present tense, indicative mood, and active voice. Compare below::

(3) I warn you not to do that again.

(4) He warned his daughter not to do that again.

The performative utterance (3) completes the speech act of warning, while the substitution of personal pronoun and the change of tense in case of (4) makes the utterance constative, not performative, thus describing an action, not performing it.

Structurally, a performative utterance can be presented by the following performative formula: $\mathrm{F}(\mathrm{p})$, where $\mathrm{F}$ and $\mathrm{p}$ stand for illocutionary force and proposition, respectively. Being borrowed from logic, in linguistics the term 'proposition' has become an essential constituent of pragmatics and semantics. According to Fasold and Connor-Linton proposition is 'the meaning of the sentence' (2013, p. 142). It denotes an expression in a language or signs of something that can be believed, doubted, or denied, or is either true or false. Illocutionary force represents the speaker's intention in pronouncing this utterance, i.e. speaker's intention is actualized in the utterance by means of a performative verb. Compare below:

(5) I promise I will lend you a hand with washing up.

The proposition in (5) refers the action of 'lending a hand with washing up' to the speaker, while the speaker's intention of uttering is cognised only through the performative verb 'promise', so the speaker wants to assure his/her interlocutor that (s)he will definitely do the action expressed in the proposition. However, the referred action in proposition in this case fails to pass verification of truth conditions, as the speaker's sincerity can be assessed only when the referred in the proposition action is performed.

All the above mentioned characteristics of performative utterances contributed to the speech act 'trinity': locution, illocution and perlocution. They represent various stages of an utterance and can be regarded as separate acts. The locutionary act corresponds to the meaning of an utterance; the illocutionary act performs the speaker's intention in pronouncing the phrase; and the perlocutionary act determines the effect on the interlocutor. Speech act theory has been a field for debate in analytic philosophy, logic and linguistics. From a linguistic point of view, the illocutionary act is a cornerstone of the theory as it focuses on the speaker's intention. However, César Félix-Brasdefer (2014) points out that the pragmatic interpretation also depends on the hearer's interpretation of the utterance under the appropriate circumstances. For example, a 'simple' phrase in a dialogue 'do you have coffee to go?' can be interpreted as a request for information with the response 'yes, we do' or as an order which will be logically answered with a counter-question 'cream and sugar?'.

Van Dijk (1979) states that such situated contexts which occur in a conversation create speech act sequences, which he thought to be significant in the relations between speech acts and the ways these relations are expressed in the sentences. César FélixBrasdefer (2014) also highlights that alongside with generally known situated contexts such as court trials, news interviews, political debates, classroom lectures, modern technologies and ways of communication create extensive data for analysis via skype calls and social networking messages.

Thetaxonomyof speechactsprovokedaconsiderable discussion in linguistics. Austin's (1962) original lexical classification of the so-called illocutionary verbs identified five groups: expositives, commissives, exercitives, verdictives, behabitives. However, Searle (1975) proposed 'pure' speech acts taxonomy which 
was based on four main criteria: 'illocutory point', 'direction of fit', 'speaker's psychological state' and 'propositional content'. Accordingly, Searle (1975) determined five classes: commissives (the same name as Austin's), directives, representatives, expressives, declarations. Among other classifications there are important works by Vendler (1972), Bach and Harnish (1972), Wierzbicka (1987), and Allan (1994).

As the aim of the current paper does not imply a thorough investigation of speech acts taxonomy and principles of their classification, the author will adhere to Searle's one, which first, according to Proost (2009), serves as a 'prototype' for other classifications and, second, fully satisfies the needs of the current research and enables us to structure the analysis and discussion section.

\section{Aim of the Research}

The main goal of this paper is to explore structural-semantic and functional-semantic features of commissive performative utterances. In particular, the goal is to establish the correlation between illocutionary force of an utterance and temporal-aspectual forms of verbs in the proposition of commissives 'promise', 'swear' and 'bet'. The frequency of aspectual-temporal form of verbs in commissive performative utterances and the types of syntactic structures used in their proposition are also considered in the research. Besides, the analysis of tense forms of verbs in propositions of promise, swear and bet, might be a basis for a new taxonomy of performative verbs.

The empirical data of the current research includes the analysis of temporal characteristics of proposition in performative utterances of commissive speech acts. The classes of declarations and directives are excluded from the analysis as in the current study only explicit performative clauses are considered, while declaratives and directives have implicit structure, that is, there is no performative verb in first person singular in Present Indefinite, which leads to the absence of proposition as such. Unfortunately, the format and the size of the current paper do not allow to examine all three remaining classes (commissives, expressives and representatives), so the focus is given to the analysis of commissive speech acts as they represent the most numerous class of performative speech acts. In the analysis, most representative performative verbs of commissives are considered. By most representative verbs are meant most frequently used verbs in English according to Macmillan Dictionary, which shows 90\% of the time, speakers of English use just 7,500 words in speech and writing. These words appear in red, and are graded with stars. One-star words are frequent, twostar words are more frequent, and three-star words are the most frequent.
Traditionally, the investigation of speech acts has been based on introspection and the analysis of artificial examples. The scare implementation of corpus-based studies can be explained by the significant role of the context utterances are used in, which is vitally important for pragmatics and discourse, but largely ignored in corpora (McEnery \& Wilson, 1996). Kohnen (2000) clarifies that the difficulties in tracing speech acts in corpora can be explained by the absence of correlation between form and function, that is, one speech act can be actualized by various utterances in different contexts. Nevertheless, Valkonen (2008) shows that corpusbased studies of speech acts can be considered viable though the use of 'computerised method for identifying and retrieving explicit performatives'. Stating that the number of explicit performative formulae is finite, Valkonen (2008) proves on the examples of two corpora (A Representative Corpus of Historical English Registers and the Chadwyck-Healey Eighteenth Century Fiction database) that the automatic search of certain inquiries can be quite effective and time-saving for a researcher.

The main method applied in the research is continuous sampling method. The data set used in the study is a collection of literary works by modern English-speaking writers: Dan Brown, John Grisham, Charlaine Harris, Chuck Palahniuk, Mario Puzo, Joanne K. Rowling, John Ronald Tolkien and others. All the works have been converted into pdf and combined into one set of files, so that the search could be conducted in a more convenient way. The search itself represented a two-stage process. First, with the help of computer programs Abby FineReader and Adobe Reader, the author typed in the search bar the following pattern 'I + performative verb (Present Indefinite indicative mood, and active voice) and obtained the examples of 2,900 utterances. At the second stage of the search, all the examples were checked manually against felicity conditions. As the result of the manual verification the list of 2,900 findings narrowed down to 1,800 utterances. Then the obtained examples were analysed in terms of temporal-aspectual forms of verbs and syntactic structures of their propositions.

\section{Results and Discussion}

The current section of the paper is divided into two parts, corresponding to the number of examined aspects in the class of commissives. First, temporalaspectual forms of verbs in proposition are discussed, and then syntactic structures applied in propositions of commissive performative utterances are scrutinized. All the results of quantitative analysis are presented in pie charts. 
Temporal-Aspectual Forms of Verbs in Proposition of Commissives

Commissives are the least arguable class of speech acts as they can be found in both Austin's and Searle's taxonomies. The illocutionary force of commissives is to oblige the speaker to perform some action or to bring about some state of affairs, that is, to commit the speaker to a future action. They may be in the form of promises, offers, threats and vows. The most typical 'artificial' example of commissives are 'I promise to come at 5 p.m. sharply', 'I swear to bring back the book', and 'I bet he won't do that again'. According to Macmillan Learner's Dictionary, verbs 'swear' and 'bet' are ranked as 'more frequent' (two stars), and verb 'promise' is 'the most frequent' (three stars).

The analysis shows that verbs in the proposition of 'promise' and 'swear' have different temporalaspectual forms (see Figure 1). As one can see on the pie charts, the majority of verbs in the proposition of the commissive 'promise' refer to the future aspect (80\%) while the aspectual-temporal form of present constitute only 20 percent of all the examples obtained through the study. For example:

(6) 'I promise you that you will be squared away with Johnny Santadio. You'll have nothing to worry about' (Puzo, 1979, p. 313);

(7) 'I promise you I am studying very hard in case this is the means I have to turn to' (Tan, 2005, p. 157).

It is argued that the high frequency of future temporal-aspectual forms of verb in the proposition of commissive 'promise' can be explained by its semantic meaning, that is, to tell someone that you will definitely do something. Thus, by giving a promise, a speaker unintentionally refers to a future action that (s)he will perform to fulfill his/her promise, which also explains the absence of past temporal-aspectual forms. In terms of logic, it is impossible to promise to carry out an action which has already been performed.

As for the commissive 'swear', it can be stated that the half of all the examples of verbs in the proposition have past temporal-aspectual forms, approximately a third of all examples refer to future and 20 percent to present temporal-aspectual forms (see Figure 1). For example:

(8) 'I swear we weren't discussing this case in particular' (Grisham, 2006, p. 67);

(9) 'I swear I'm innocent. I swear on the head of my children I'm innocent' (Puzo, 1970, p. 368);

(10) 'I can't. It's been too long, next time I swear I'll be sweet' (Harris, 2002, p. 48).

Comparing the use of temporal-aspectual forms of verbs in the proposition of 'promise' and 'swear', it should be noticed that in spite of the fact that both verbs are classified as commissives, their main temporal-aspectual references vary: the most frequent tense forms used in the proposition of 'promise' refer to future while in the proposition of 'swear' to past. Another peculiarity concerning these two commissives is that the second most frequent aspectual form in proposition of both is present; with the same proportion of 20 percent each. However, they have different temporal perspectives: swear is classified as mobile performative, that is, a verb used in its proposition can acquire three temporal-aspectual forms while promise is regarded as non-mobile due to the absence of future temporal-aspectual forms of verbs in its proposition.

The last but not the least peculiarity is that swear becomes the synonym to promise provided that the verb in its proposition refers to future aspect. Therefore, promise in (6) and (7) can be replaced by swear with little, if any, change in the meaning of the utterances. This fact is also proved by semantics of the verb 'swear'. According to Macmillan Dictionary swear, alongside with its main definition 'to make a sincere statement that you are telling the truth' also has the second one 'to make a promise to do something'.

Commissive 'bet', as well as performative 'swear', has a full-scale frame of temporal-aspectual forms of verbs in the proposition: past, present and future. The most frequent is present temporal-aspectual form, which is virtually a half $(45 \%)$ of all the examples in the data while present and past temporal-aspectual
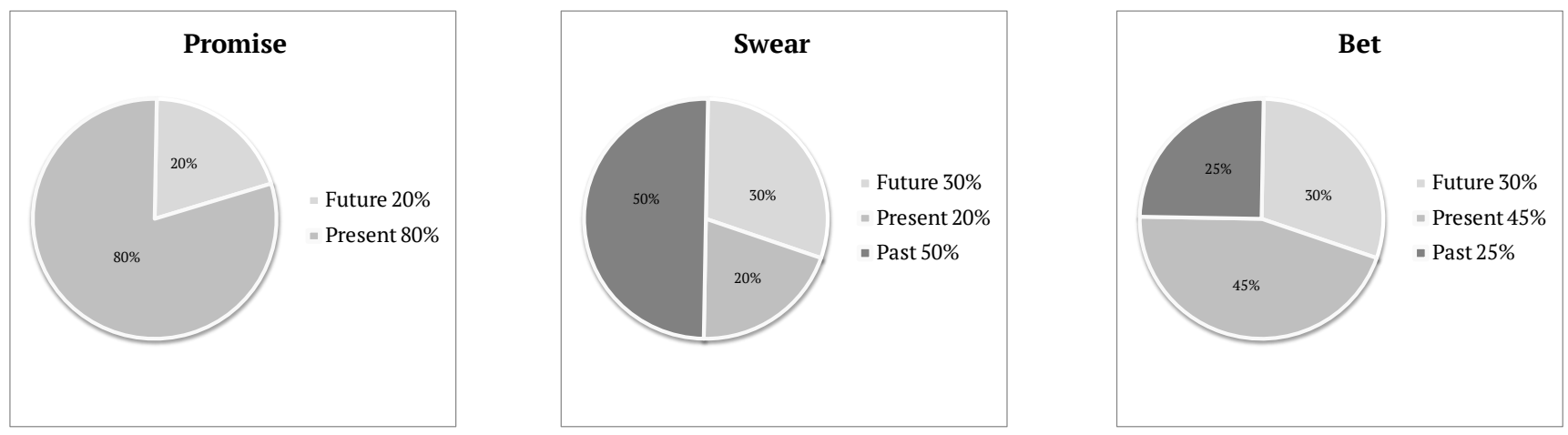

Figure 1. Temporal-aspectual forms of commissives 'promise', 'swear', \& 'bet'. 
forms have the almost the same frequency with 30 and 25 percent respectively. See the examples below

(11) 'I bet whoever did it was the prowler I had Saturday night' (Cruise, 2004, p. 227);

(12) 'I bet he's learning loads' (Rowling, 2001, p. 11);

(13) 'I have no problem with that, Patrick. No one is screaming for you to be moved to the jail. Not yet. But I bet the press will start soon' (Grisham, 2005, p. 185).

The obtained data makes it clear that in case of 'bet' the difference in figures among three temporalaspectual forms is greater than in those of 'promise' and 'swear'. This can be explained by semantic meaning of the verb 'bet' as a speaker uttering a phrase with 'I bet' can be fairly sure not only about the events of the past, but also about the facts and activities in present and possible future actions.

\section{Syntactic Structures in Propositions of Commissives}

The next aspect to analyse within this class of speech acts is syntactic structures applied in the proposition of 'promise', 'swear' and 'bet'. Figure 2 indicates that the most frequent type of syntactic structures in propositions of these commissives is simple sentence structure. It constitutes almost the same percentage of all the examples obtained in the course of research ( $75 \%$ for 'promise', 70\% for 'swear' and $73 \%$ for 'bet'). Here are some illustrative examples:

(14) 'I promise you I will never let him come to harm' (Novik, 2006, p. 111);

(15) 'I swear I know nothing about any embezzlement. I am an honest man' (Brown, 2002, p. 147);

(16) 'I bet it still hurts' (Sands, 2009, p. 202).

Complex sentence is the second most frequent syntactic structure with a coverage of $20 \%$ for all the performative verbs under the study. Some examples are:

(17) 'I really need to know. I promise that as soon as you tell me, I will tell you everything about last night' (Brennan, 2004, p. 7);

(18) 'I swear I will remember where I'm supposed to go to school' (Rowling, 2000, p. 204);

(19) 'I bet he slept with you, when you were together' (Goodkind, 2008, p. 828).

The use of compound sentence structure shows the most noticeable difference; it is two times more frequent in the proposition of 'promise' than in the proposition of 'swear' with 10 and 5 percent correspondingly, while in the proposition of 'bet' this figure makes up 7 percent. Some examples are given below:

(20) 'But, I promise you that for every horror you will have to face and you will also discover great joy' (Dennis, 2009, p. 58).

(21) 'I swear, one woman actually plopped herself in Luc's lap and she propositioned him for everyone to hear' (Sands, 2003 p. 176);

(22) 'I bet I could tell Sam to go wait for me in the forest, and he would do that' (Dennis, 2009, p. 148).

The extensive use of simple sentence structure, compared to complex and compound ones, in proposition of commissives can be explained by the context of dialogue speech these utterances are used in. Performative formula 'I (hereby) verb-presentactive $\mathrm{X}$...' is one of the distinctive features of dialogue speech which, in its turns, is characterised by the simplicity of syntactic structures. For the same reason the occurrence of complex and compound sentence structures in propositions of swear, promise and bet is a lot less frequent.

\section{Conclusion}

The main aim of the research was to explore the temporal-aspectual forms of verbs in propositions of performatives 'promise', 'swear' and 'bet' and to reveal the syntactic structures of their propositions. It has been explained on the examples of commissive speech acts that the illocutionary force alongside with semantic meaning of performative verb predetermines the use of temporal-aspectual forms of verbs in the
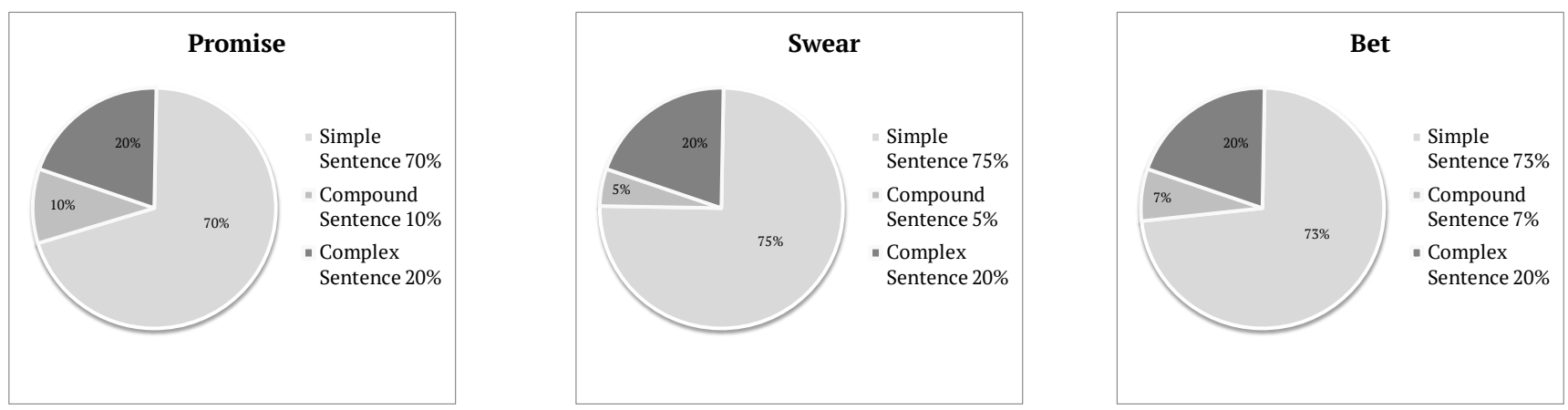

Figure 2. Syntactic structures of commissives 'promise', 'swear' and 'bet'. 
proposition of commissives. After a thorough analysis of commissive speech acts, it can be concluded that performative verb 'promise' has a narrowed temporal perspective as verbs used in its proposition have no past temporal-aspectual forms. Performative verbs 'swear' and 'promise' have extended temporal perspective. In other words, temporal-aspectual forms of verbs in their propositions refer an action to past, present and future.

As for the syntactic structures used in propositions of commissives 'promise', 'swear' and 'bet', it can be stated that the main one is a simple sentence structure which prevails over complex and compound sentence structures. The extensive use of simple sentence structure can be explained by the main feature of dialogue speech in which commissive speech acts are employed.

In spite of the profound analysis of the data, the results of the investigation cannot be proclaimed finite as more extensive corpora need to be studied. The current findings highlight the trends in the use of temporal-aspectual forms of verbs in propositions; however; there might be some discrepancies after broader data analysis.

The results of current study also have some practical applications in teaching English as a foreign language. The data collected in the course of the study might be used to promote learners' awareness of two aspects: grammar and sociolinguistic competence. In terms of the former, some exercises might be designed to practise the use of tense forms in propositions of performative verbs. The latter might facilitate the process of the contextual analysis which in its turn will help to use naturally commissive speech acts in spoken and written English discourses. The further research on the topic can be conducted in the following ways. First, it might be fruitful to analyse the temporal-aspectual forms of verbs in propositions of other explicit speech acts (i.e. expressives and representatives), and to compare the findings with those of the current paper. Second, the investigation of classes of expressives and representatives might approve or disapprove the correlation between the illocutionary force of these speech acts and temporal-aspectual forms of verbs in propositions. Finally, the investigation of temporalaspectual forms in various discourses like political speeches or legal debates appeals to be interesting in terms of sociolinguistics and the Speech Act Theory.

\section{References}

Allan, K. (1994). Speech act classification and definition. In R. Asher (Ed.), Encyclopedia of language and linguistics (pp. 4124-4127). Oxford, UK: Pergamon Press.
Austin, J.L. (1962). How to do things with words. London, UK: Oxford University Press.

Bach, K., \& Harnish, R. M. (1979). Linguistic communication and speech acts. Cambridge, MA: MIT Press.

Brennan, F. (2004). Fruitcake special. Cambridge, UK: Cambridge University Press.

Brown, D. (2002). Deception point. Washington, DC: Square Press.

César Félix-Brasdefer, J. (2014). Speech act sequences. In K. P. Schneider \& A. Barron (Eds.), Pragmatics of discourse (pp. 323-352). Berlin, Germany: Walter de Gruyter GmbH.

Cruise, J. (2004). Tell me lies. New York, NY: St. Martin's Press.

Dennis, K. (2009). In less than a second. Phoenix, AZ: Kerry Dennis Publisher.

Fasold, R., \& Connor-Linton, J. (2013). An introduction to language and linguistics. Cambridge, UK: Cambridge University Press.

Goodkind, T. (2008). Faith of fallen (Sword of truth). London, UK: Gollancz.

Grisham, J. (2005). The partner. New York, NY: Penguin Random House Publishing Group.

Grisham, J. (2006). The run away jury. New York, NY: Doubleday Books.

Harris, Ch. (2002). Living dead in Dallas. London, UK: Ace Books.

Kohnen, T. (2000). Corpora and speech acts: The study of performatives. In Ch. Mair \& M. Hundt (Eds.), Corpus linguistics and linguistic theory. Papers from the twentieth international conference on English language research on computerized corpora (ICAME 20) (pp. 177-186). Amsterdam, Netherlands: Rodopi.

McEnery, T., \& Wilson, A. (1996). Corpus linguistics. Edinburgh, UK: Edinburgh University Press.

Novik, N. (2006). His majesty's dragon. New York, NY: Del Rey.

Proost, K. (2009). Speech act verbs. In J. L. Mey (Ed.), Concise encyclopedia of pragmatics (2nd ed.) (pp. 995-1000). Oxford, UK: Elsevier Science.

Puzo, M. (1970). The godfather. New York, NY: G. P. Putnam's Sons.

Puzo, M. (1979). Fools die. New York, NY: Signet.

Rowling, J. K. (2000). Harry Potter and the Chamber of secrets. New York, NY: Scholastic Paperbacks.

Rowling, J. K. (2001). Harry Potter and the prisoner of Azkaban. New York, NY: Scholastic Paperbacks.

Sands, L. (2003). Single white vampire. New York, NY: Dorchester Publishing.

Sands, L. (2009). Love bites. New York, NY: Dorchester Publishing.

Searle, J. R. (1975). A taxonomy of illocutionary acts. In K. Gunderson (Ed.), Language, mind and knowledge (pp. 344-379). Minneapolis, MN: University of Minneapolis Press. 
Tan, A. (2005). The bonesetter's daughter. New York, NY: G. P. Putnam's Sons.

Valkonen, P. (2008). Showing a little promise: Identifying and retrieving explicit illocutionary acts from a corpus of written prose. In A. H. Jucker \& I. Taavitsainen (Eds.), Speech acts in the history of English (pp. 223-248). Amsterdam, Netherlands: John Benjamins.

van Dijk, T. (1979). Pragmatic connectives. Journal of
Pragmatics, 3, 447-456.

Vendler, Z. (1972). Res cogitans. Ithaca, NY: Cornell University Press.

Wierzbicka, A. (1987). English speech act verbs: A semantic dictionary. Sydney, Australia: Academic Press.

Wittgenstein, L. (1953). Philosophical investigation. Oxford, UK: Basil Blackwell. 